\title{
COMUNICAC̣̃̃O
}

\section{ANÁLISE DE SISTEMAS GENE MARCADOR/AGENTE SELETIVO ALTERNATIVOS PARA SELEÇÃO POSITIVA DE EMBRIÕES SOMÁTICOS TRANSGÊNICOS DE MAMOEIRO}

\author{
SOUZA JÚNIOR, M. T. ${ }^{1,3}$; VENTUROLI, M. F. ${ }^{2}$; COELHO, M. C. F. ${ }^{1}$, \\ RECH FILHO, E. L. ${ }^{1}$
}

Laboratório de Transformação e Expressão de Genes, Cenargen, Embrapa.

RESUMO - Questões relacionadas à biossegurança de organismos geneticamente modificados e à percepção pública destes têm levado as instituições envolvidas no desenvolvimento comercial de plantas transgênicas a abandonarem o uso de genes marcadores que conferem resistência a antibióticos. $\mathrm{O}$ desenvolvimento de mamoeiros (Carica papaya L.) transgênicos tem sido baseado, até o momento, no uso de um único gene marcador, o gene npt II, que confere resistência a antibióticos como canamicina e neomicina. O presente estudo objetivou avaliar os sistemas alternativos $\mathrm{manA} /$ manose e $\mathrm{bar} / \mathrm{PPT}$ como sistemas gene marcador/ agente seletivo para a variedade 'Sunrise' de mamoeiro. O desenvolvimento de embriões somáticos secundários a partir de embriões primários foi avaliado em meio de indução de embriogênese suplementado com manose e/ou sacarose. Concentrações variando entre $0,1 \mathrm{e} 120 \mathrm{~g} / \mathrm{l}$ de manose foram testadas como única fonte de carbono, ou em combinação com sacarose. $\mathrm{O}$ desenvolvimento de embriões somáticos secundários a partir dos primários em meio suplementado com até 120 g.L $\mathrm{L}^{-1}$ de manose, como única fonte de carbono, demonstrou que este sistema não é passível de uso no desenvolvimento de mamoeiros transgênicos. Quanto ao sistema bar/ PPT, avaliou-se o desenvolvimento de embriões somáticos primários e secundários em meio suplementado com concentrações de PPT variando de zero a $150 \mu \mathrm{M}$. Não foi observado desenvolvimento de embriões em meio suplementado com concentração igual ou superior a $125 \mu \mathrm{M}$, o que sugere o uso desta concentração para a seleção de embriões transgênicos de mamoeiro.

TERMOS ADICIONAIS PARA INDEXAÇÃO: glufosinato de amônio, PPT, manose, gene $P M I$, gene Bar e transformação genética.

Recebido: 23/3/2001- Aceito: 1/12/2001

1. Pesquisador, EMBRAPA/Recursos Genéticos e Biotecnologia (Cenargen), Parque Estação Biológica, Final Avenida W5 Norte, Caixa Postal 02372, Brasília - DF, 70770-900

2. Estudante de Biologia, Universidade Católica de Brasilia (UCB). Bolsista EMBRAPA/Programa Avança Brasil

3. Autor para correspondência: msouza@cenargen.embrapa.br 


\title{
ANALYSIS OF MARKER GENE/SELECTIVE AGENT SYSTEMS ALTERNATIVES TO POSITIVE SELECTION OF TRANSGENIC PAPAYA (CARICA PAPAYA L.) SOMATIC EMBRYOS.
}

\begin{abstract}
Questions relative to biosafety and public perception of genetically modified organisms have taken those involved on the development of transgenic plants to a phase out on the use of antibiotic resistance marker genes. The development of transgenic papayas (Carica papaya L.) has been based so far on the use of one only marker gene, the npt II gene, which confers resistance to antibiotics such as kanamycin and neomycin. The present study aimed to evaluate the systems $\mathrm{manA} /$ mannose and $\mathrm{bar} /$ PPT as alternatives marker gene/ selective agent systems to be used on the development of transgenic 'Sunrise' papayas. Therefore, the development of secondary somatic embryos from primary ones was evaluated on embryogenesis induction medium supplemented with mannose and/or sucrose. Mannose concentration ranging from 0.1 to 120 g. $\mathrm{L}^{-1}$ were tested as sole carbon source, or in conjunction with sucrose. The development of secondary somatic embryos on medium supplement with up to $120 \mathrm{~g} / \mathrm{l}$, as sole carbon source, demonstrated that this system is not applicable for the development of transgenic papayas. When evaluating the bar/ PPT system, the development of primary and secondary somatic embryos was checked for on medium supplement with zero to $150 \mu \mathrm{M}$ of PPT. No somatic embryos developed on medium supplemented with PPT at $125 \mu \mathrm{M}$ or more, what suggests the use of this concentration for the in vitro selection of transgenic papaya embryos.
\end{abstract}

ADDITIONAL INDEX TERMS: Phosphinothricin, PPT, mannose, PMI gene, Bar gene, and genetic transformation.

\section{INTRODUÇÃO}

O processo de desenvolvimento de organismos geneticamente modificados (OGM), também conhecidos como "transgênicos", depende do uso de sistema gene marcador/ agente seletivo que permita a seleção positiva de células transformadas. Os sistemas baseados na utilização de genes que conferem resistência a antibióticos e/ou herbicidas têm sido utilizados no desenvolvimento de OGMs vegetais desde os primórdios da engenharia genética, sendo que todos os OGMs vegetais já liberados para comercialização no mundo, até o momento, apresentam um dos dois, ou os dois tipos de genes acima descritos. Porém, questões ligadas à biossegurança e à percepção pública dos OGMs, principalmente no que se refere ao uso de sistemas tipo gene de resistência a antibiótico/ antibiótico, têm sinalizado para a necessidade de se procurar sistemas alternativos a estes (FDA/CFSAN, 1998; Smith, 2000). Neste contexto, têm surgido não só sistemas gene marcador/ agente seletivo alternativos, como também sistemas que permitem a eliminação do gene marcador após a seleção (Ow, 2000; Zubko et al., 2000).

A produção de mamoeiros (Carica papaya L.) geneticamente modificados é uma realidade desde o início da década de 90, quando Fitch et al. (1992) produziram o primeiro mamoeiro transgênico resistente ao Papaya ringspot virus (PRSV), que foi denominado linha 55-1. Esta linha transgênica foi utilizada no desenvolvimento das variedades 'Rainbow' e 'SunUp', que foram os primeiros mamoeiros transgênicos liberados para comercialização no mundo, o que ocorreu em 1998 no Havaí (Gonsalves, 1998). A linha 55-1 apresenta o gene npt II [que codifica a enzima APH(3')II aminoglycoside 3 '-phosphotransferase II, também conhecida como NPT II - neomycin phosphotransferase II] (Beck et al., 1982) e foi selecionada in vitro utilizando canamicina como agente seletivo. Desde então diversos mamoeiros transgênicos com resistência a vírus ou tolerância a 
herbicida foram desenvolvidos (Cabrera-Ponce et al., 1995; Cheng et al., 1996; Tennant, 1996; Cai et al., 1999; Souza Jr., 1999), sendo que todos utilizaram o sistema gene npt II/ canamicina na seleção.

O sistema que usa o gene manA (que codifica a enzima PMI - phosphomannose isomerase) de Escherichia coli (Miles e Guest, 1984), tendo a manose como agente seletivo, é um dos novos sistemas sugeridos como alternativos aos dois primeiros descritos acima (Joersbo et al., 1998; Ow, 2000). As espécies vegetais que não metabolizam manose sofrem severa inibição de crescimento quando esta é oferecida como única fonte de carbono em meio de cultura. Os efeitos adversos e inibitórios do uso da manose são conseqüências do acúmulo de manose 6-fosfato, produto da fosforilação da manose por uma hexoquinase. PMI promove a interconversão de manose 6-fosfato e frutose 6-fosfato, permitindo assim que a primeira possa ser catabolizada na via glicolítica (Ferguson e Street, 1958; Malca et al., 1967).

O gene bar (que codifica a enzima PAT phosphinothricin-N-acetyltransferase) de Streptomyces hygroscopicus (Murakani et al., 1986), tendo o glufosinato de amônio (PPT) como agente seletivo, é, dentre os sistemas tipo gene de tolerância a herbicida/ herbicida, um dos mais amplamente empregados pela engenharia genética no desenvolvimento de OGMs vegetais. PAT inativa herbicidas que apresentam o PPT como composto ativo mediante detoxificação deste. A detoxificação, que é resultante da acetilação do grupamento amino livre presente no PPT, torna este incapaz de competir de forma inibitória com a glutamina sintetase (GS), possibilitando assim a remoção da amônia tóxica da célula vegetal pela conversão de glutamato em glutamina, reação esta catalizada pela GS (Lindsey, 1992).

O objetivo do presente estudo foi avaliar os sistemas manA/ manose e bar/ PPT no processo de transformação genética do mamoeiro 'Sunrise', uma das principais cultivares desta fruteira em nível mundial. Para tanto, a análise da indução e do desenvolvimento de embriões somáticos primários e/ou secundários, sob diferentes concentrações do agente seletivo, se fez necessária. Embriões somáticos primários e/ou secundários de mamoeiro são os explantes utilizados na transformação genética desta fruteira no nosso laboratório.

\section{MATERIAL E MÉTODOS}

Embriões zigóticos foram excisados a partir de frutos imaturos da cultivar 'Sunrise', coletados no campo com aproximadamente 90 a 110 dias da antese, e submetidos à indução de embriogênese somática conforme Souza Jr. (1999). Os embriões zigóticos e os somáticos submetidos aos diferentes tratamentos foram cultivados in vitro a $27{ }^{0} \mathrm{C}\left(+/-2{ }^{0} \mathrm{C}\right)$, no escuro, por um período médio de 45 dias.

Para a avaliação do sistema manAl manose, embriões somáticos primários, obtidos por embriogênese direta a partir de embriões zigóticos imaturos, foram cultivados em meio de indução de embriogênese - PIM10 (Souza Jr., 1999) suplementado com diferentes concentrações de sacarose e/ou manose (Tabela 1). Cada tratamento teve entre quatro e cinco repetições (isto é, placas de petri), e a avaliação se deu pela presença ou total ausência de embriões somáticos secundários ao final do período de cultivo.

Para a avaliação do sistema Bar/ PPT, embriões zigóticos e somáticos primários foram cultivados em PIM10 suplementado com diferentes concentrações de PPT (Tabela 2). Cada tratamento com embriões zigóticos utilizou pelo menos 30 embriões, enquanto que cada tratamento com embriões somáticos teve pelo menos três repetições (placas de petri). A avaliação se deu para presença ou total ausência de embriões somáticos primários a partir dos zigóticos, ou somáticos secundários a partir dos primários, ao final do período de cultivo. 
TABELA 1. Indução de embriões somáticos secundários em meio de cultura suplementado com diferentes combinações sacarose:manose (em gramas por litro).

\begin{tabular}{cccc}
\hline Tratamento & Resposta & Tratamento & Resposta \\
\hline Sacarose 0, Manose 0 & Negativo* & Sacarose 0, Manose 0.1 & Negativo \\
Sacarose 0.1, Manose 0 & Negativo & Sacarose 0, Manose 0.3 & Negativo \\
Sacarose 0.3, Manose 0 & Negativo & Sacarose 0, Manose 0.5 & Negativo \\
Sacarose 0.5, Manose 0 & Negativo & Sacarose 0, Manose 1.5 & Negativo \\
Sacarose 30.0, Manose 0 & Positivo & Sacarose 0, Manose 3.0 & Negativo \\
Sacarose 60.0, Manose 0 & Positivo & Sacarose 0, Manose 30.0 & Positivo \\
Sacarose 60.0, Manose 0.5 & Positivo & Sacarose 0, Manose 60.0 & Positivo \\
Sacarose 60.0, Manose 1.5 & Positivo & Sacarose 0, Manose 90.0 & Positivo \\
Sacarose 60.0, Manose 3.0 & Positivo & Sacarose 0, Manose 120.0 & Positivo \\
\hline
\end{tabular}

* Resposta "Negativo" indica total ausência de novos embriões somáticos após 45 dias de cultivo, enquanto que resposta "Positivo" indica desenvolvimento de novos embriões somáticos.

\section{RESULTADOS E DISCUSSÃO}

O sistema manA/ manose: Quando sacarose ou manose foram oferecidas como única fonte de carbono, em concentração igual ou inferior a três gramas por litro, não foi observado desenvolvimento de novos embriões somáticos de mamoeiro (Tabela 1). Os embriões somáticos primários, submetidos a estes tratamentos, adquiriram uma coloração marrom, contrastante com a coloração amarelo claro normalmente observada; e, além de não produzirem novos embriões, estes também cessaram o seu próprio desenvolvimento (Figura 1). As respostas similares, tanto para os tratamentos com sacarose quanto para os com manose, sugerem que a resposta observada nos tratamentos com manose resulta da falta de suficiente fonte de carbono, e não de nenhum efeito tóxico decorrente da presença deste açúcar.
O meio de indução de embriogênese somática em mamoeiro é normalmente suplementado com 60 g. $\mathrm{L}^{-1}$ de sacarose (Cai et al., 1999; Souza Jr, 1999). Nossos resultados (Tabela 1) mostram que quando esta concentração de sacarose foi utilizada, juntamente com manose em concentração igual ou inferior a três gramas por litro, não foi observado nenhum efeito adverso na produção de novos embriões somáticos. Não havia distinção de resposta entre o tratamento que utilizou somente sacarose $\left(\begin{array}{lll}60 & \text { g. } L^{-1}\end{array}\right)$ e os tratamentos que usaram sacarose $(60 \mathrm{~g} / \mathrm{l})$ e manose $\left(0,5\right.$ a 3,0 g. $\left.\mathrm{L}^{-1}\right)$. Joersbo et al. (1998) observaram uma interação entre sacarose e manose quando estes foram oferecidos como fonte de carbono em meio de cultura para formação de brotos de beterraba açucareira (Beta vulgaris L.). Esta interação se manifestou como redução na porcentagem de formação de brotos, a qual se acentuou com o aumento da concentração de manose para uma concentração específica de sacarose, ou com a diminuição da concentração de sacarose. 


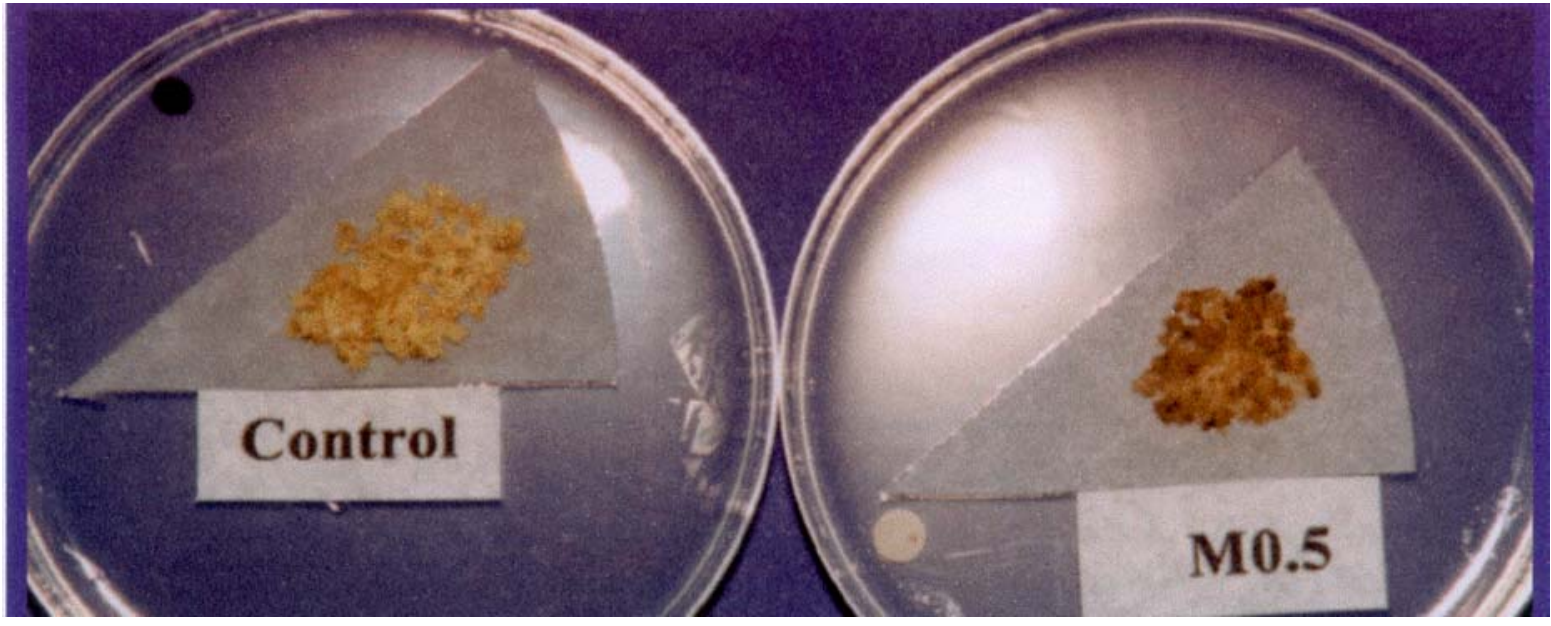

FIGURA 1. Desenvolvimento de embriões somáticos secundários de mamoeiro (Carica papaya L.) in vitro, em meio de indução de embriogênese suplementado com 60 g. $\mathrm{L}^{-1}$ de sacarose (Control) e 0,5 g. $\mathrm{L}^{-1}$ de manose (M0,5), como única fonte de carbono

TABELA 2. Indução de embriogênese somática a partir de embriões zigóticos e de embriões somáticos primários em meio de cultura suplementado com diferentes quantidades de glufosinato de amônio (PPT).

\begin{tabular}{lccc}
\hline Tratamento & Resposta & Tratamento & Resposta \\
\hline Embrião Zigótico vs. PPT 0* & $38 / 40^{* *}$ & Embrião Somático vs. PPT 0 & +++ \\
Embrião Zigótico vs. PPT 0.5 & $29 / 30$ & Embrião Somático vs. PPT 0.5 & +++ \\
Embrião Zigótico vs. PPT 1.0 & $20 / 20$ & Embrião Somático vs. PPT 1.0 & +++ \\
Embrião Zigótico vs. PPT 2.5 & $20 / 20$ & Embrião Somático vs. PPT 2.5 & +++ \\
Embrião Zigótico vs. PPT 5.0 & $19 / 20$ & Embrião Somático vs. PPT 5.0 & +++ \\
Embrião Zigótico vs. PPT 10.0 & $19 / 20$ & Embrião Somático vs. PPT 10.0 & +++ \\
Embrião Zigótico vs. PPT 25.0 & $29 / 30$ & Embrião Somático vs. PPT 25.0 & ++ \\
Embrião Zigótico vs. PPT 50.0 & $22 / 30$ & Embrião Somático vs. PPT 50.0 & ++ \\
Embrião Zigótico vs. PPT 100.0 & $3 / 60$ & Embrião Somático vs. PPT 100.0 & + \\
Embrião Zigótico vs. PPT 125.0 & $0 / 20$ & Embrião Somático vs. PPT 125.0 & Negativo \\
Embrião Zigótico vs. PPT 150.0 & $0 / 20$ & Embrião Somático vs. PPT 150.0 & Negativo \\
\hline * Concentração de PPT em $\mu$ M. & \\
** Resposta dos tratamentos usando embriões zigóticos dada em números de embriões positivos para aparecimento \\
de embriões somáticos por número de embriões testados. Resposta de embriões somáticos primários dada em \\
termos de produção ou não (Negativo) de novos embriões, e quantidade (+++ grande quantidade, ++ média, + \\
pouca).
\end{tabular}


Quando oferecida como única fonte de carbono, sob concentração variando de 30 a 120 g. $L^{-1}$, a manose não demonstrou efeito adverso ou inibidor no desenvolvimento de novos embriões somáticos de mamoeiro (Tabela 1), com esses embriões apresentando forma e coloração similar aos embriões obtidos em meio suplementado com sacarose $\left(60\right.$ g.L $\left.\mathrm{L}^{-1}\right)$ (Figura 1). Embora todos esses tratamentos possibilitaram o desenvolvimento de embriões somáticos secundários, observou-se uma redução na quantidade de novos embriões produzidos à medida que a concentração de manose aumentava. Esta redução na quantidade de novos embriões produzidos pode ser resultado de um efeito tóxico da manose, ou do potencial osmótico da solução com alta concentração deste açúcar no meio. Estes resultados sugerem que o mamoeiro esta entre as espécies vegetais capazes de metabolizar manose. Como conseqüência disso, o sistema manA/ manose não se mostra passível de uso no processo de seleção positiva de transformantes em programas de transformação genética de mamoeiro 'Sunrise'.

O sistema bar/PPT: A produção de embriões somáticos primários a partir de embriões zigóticos imaturos foi afetada somente nas maiores concentrações de PPT testadas; isto é, em concentração igual ou superior a $50 \mu \mathrm{M}$. Em concentração de PPT igual ou inferior a $25 \mu \mathrm{M}$, não foi observada diferença entre o controle negativo (sem PPT) e os tratamentos contendo PPT. O aparecimento de embriões somáticos a partir de zigóticos cessou completamente quando PPT foi suplementado nas concentrações 125 e 150 $\mu \mathrm{M}$ (Tabela 2).

A resposta do embrião zigótico foi considerada positiva quando dois ou mais embriões somáticos foram observados ao final do período de cultivo. Dentre os embriões com resposta positiva há uma variação na quantidade de embriões somáticos primários produzidos; este tipo de comportamento é o normalmente observado, independente da presença ou não do PPT suplementando o meio.
Quando avaliando a produção de embriões somáticos secundários a partir de embriões somáticos primários, em meio suplementado com diferentes concentrações de PPT, observou-se uma resposta bastante similar à observada quando usando embriões zigóticos. A produção de novos embriões foi afetada somente nas maiores concentrações de PPT testadas; só que neste caso, em concentração igual ou superior a 25 $\mu \mathrm{M}$. Novamente, somente nas concentrações $125 \mathrm{e}$ $150 \mu \mathrm{M}$ de PPT foi observada a paralisação total no desenvolvimento de novos embriões (Tabela 2). Cabrera-Ponce et al. (1995) é o único trabalho reportando o uso do sistema $\mathrm{Barl}$ PPT para a seleção de embriões transgênicos de mamoeiro até o momento. Porém, este sistema foi utilizando em conjunto com o sistema npt II/ canamicina, resultando uma eficiência de transformação igual a 1,42\% para a variedade de mamoeiro 'Maradol'.

Nossos resultados sugerem que, quando usando o sistema Bar/ PPT para a seleção de embriões transgênicos de mamoeiro 'Sunrise', independente do tipo de explante utilizado (embriões zigóticos ou somáticos), a seleção deve ser realizada em concentração igual ou superior a $125 \mu \mathrm{M}$ de PPT. Esta concentração, que corresponde a aproximadamente $25 \mathrm{mg} . \mathrm{L}^{-1}$, é 6,25 vezes superior à utilizada por Cabrera-Ponce et al. (1995), que foi de $4 \mathrm{mg} . \mathrm{L}^{-1}$. A diferença na concentração de PPT necessária para a seleção de embriões transgênicos observada entre CabreraPonte et al. (1995) e o presente trabalho podem ser decorrentes do uso de diferentes variedades ('Sunrise' x 'Maradol'), ou devido ao uso do sistema Bar/ PPT sozinho, ou em combinação com o sistema npt II/ canamicina.

\section{AGRADECIMENTOS}

Ao Programa Avança Brasil - Inovação Tecnológica na Fruticultura Irrigada no Nordeste Brasileiro pelo suporte financeiro para execução desse estudo. 
Análise de sistemas gene marcador/agente ...

\section{REFERÊNCIAS}

BECK, E.; LUDWIG, G.; AUERSWALD, E. A.; REISS, B. AND SCHALLER, H. Nucleotide sequence and exact localization of the neomycin phosphotransferase gene from transposon Tn5. Gene, 19: 327-336, 1982.

CABRERA-PONCE，J. L.; VEGAS-GARCIA, A. AND HERRERA-ESTRELLA, L. Herbicide resistant transgenic papaya plants produced by an efficient particle bombardment transformation method. Plant Cell Reports, 15:1-7, 1995.

CAI, W., GONSALVES, C., TENNANT, P., FERMIN, G., SOUZA JR., M. T., SARINDU, N., JAN, F. J., ZHU, H. Y. AND GONSALVES, D. A protocol for efficient transformation and regeneration of Carica papaya L. In Vitro Cellular \& Development Biology - Plant, 35: 61-69, 1999.

CHENG, Y. H.; YANG, J. S. AND YEH, S. D. Efficient transformation of papaya by coat protein gene of papaya ringspot virus mediated by Agrobacterium following liquidphase wounding of embryogenic tissues with carborundum. Plant Cell Reports, 16:127132, 1996.

FDA/CFSAN - U. S. Food and Drug Administration/ Center for Food Safety and Applied Nutrition. Guidance for Industry: Use of Antibiotic Resistance Marker Genes in Transgenic Plants. 1998. 27p. http://vm.cfsan.fda.gov/ dms/opa-armg.html

FERGUSON, J. D.; STREET, E. AND DAVID, S. B. The carbohydrate nutrition of tomato roots. IV. The inhibition of excised root growth by galactose and mannose and its reversal by dextrose and xylose. Annals of Botany, 22: 525-538, 1958.
FITCH, M., MANSHARDT, R., GONSALVES, D., SLIGHTOM, J. AND SANFORD, J. Virus resistant papaya plants derived from tissues bombarded with the coat protein gene of papaya ringspot virus. Bio/Technology, 10: 1466-1472, 1992.

GONSALVES, D. Control of papaya ringspot virus in papaya: A case study. Annual Review Phytopathology, 36: 415-437, 1998.

JOERSBO, M.; DONALDSON, I.; KREIBERG, J.; PETERSEN, S. G.; BRUNSTEDT, J. AND OKKELS, F. T. Analysis of mannose selection used to transformation of sugar beet. Molecular Breeding, 4:111-117, 1998.

LINDSEY, K. Genetic manipulation of crop plants. Journal of Biotechnology, 26: 1-28, 1992.

MALCA, I.; ENDO, R. M. AND LONG, M. R. Mechanism of glucose counteraction of inhibition of root elongation by galactose, mannose and glucosamine. Phytopathology, 57: 272-278, 1967.

MILES, J. S. AND GUEST, J. R. Nucleotide sequence and transcriptional start point of the phosphomannose isomerase gene (manA) of Escherichia coli. Gene, 32:41-48, 1984.

MURAKAMI, T.; ANZAI, H.; IMAI, S.; SATOH, A.; NAGAOKA, K. AND THOMPSON, C. J. The bialaphos biosynthetic genes of Streptomyces hygroscopicus: molecular cloning and characterization of the gene cluster. Molecular and General Genetics., 205: 42-50, 1986.

OW, D. Marker Genes. In: Joint FAO/WHO Expert Consultation on Food Derived from Biotechnology, Geneva, Switzerland, 2000. http://www.fao.org/es/esn/gm/Bio-14.pdf 
SMITH, N. Seeds of opportunity: an assessment of the benefits, safety, and oversight of plant genomics and agricultural biotechnology. Report of the subcommittee on basic research - committee on science, US House of Representatives. 89p. 2000. http://www.house.gov/science/smithreport041300.pdf

SOUZA JR., M. T. Analysis of the resistance in genetically engineered papaya against papaya ringspot potyvirus, partial characterization of the PRSV.Brazil.Bahia isolate, and development of transgenic papaya for Brazil. Ithaca, Cornell University, 1999. 277p. Tese de Doutorado.
TENNANT, P. F. Evaluation of the resistance of coat protein transgenic papaya against papaya ringspot virus isolates and development of transgenic papaya for Jamaica. Ithaca, Cornell University, 1996. 317p. Tese de Doutorado.

ZUBKO, E.; SCUTT, C. AND MEYER, P. Intrachromosomal recombination between attP regions as a tool to remove selectable marker genes from tobacco transgenes. Nature Biotechnology, 18: 442-445, 2000. 